\title{
CONTINUITY \\ AND CHANGE
}

A journal of social structure,

law and demography

in past societies

\author{
VOLUME 29 \\ 2014
}

\section{CAMBRIDGE UNIVERSITY PRESS}


PUBLISHED BY

THE PRESS SYNDICATE OF THE UNIVERSITY OF CAMBRIDGE

The Pitt Building, Trumpington Street, Cambridge CB2 1RP, United Kingdom

CAMBRIDGE UNIVERSITY PRESS

University Printing House, Shaftesbury Road, Cambridge CB2 8BS, UK

32 Avenue of the Americas, New York, NY 10013-2473, USA

477 Williamstown Road, Port Melbourne, VIC 3207, Australia

Ruiz de Alarcón 13, 28014 Madrid, Spain

Dock House, The Waterfront, Cape Town 8001, South Africa

http://www.cambridge.org

(C) Cambridge University Press 2014

Printed in the UK by Bell \& Bain Ltd, Glasgow 


\section{Contents}

\section{CONTINUITY AND CHANGE 29:1}

\section{ARTICLES}

JULIE MARFANY AND MARY LOUISE NAGATA Farewells, welcomes and grateful thanks 1

CHRIS BRIGGS Introduction: law courts, contracts and rural society in Europe, 1200-1600

JACO ZUIJDERDUiJn On the home court advantage. Participation of locals and non-residents in a village law court in sixteenth-century Holland

LLUís SALES I FAVÀ Suing in a local jurisdictional court in late medieval Catalonia. The case of Caldes de Malavella (1328-1369)

XAVIER SOLDEVILA I TEMPORAL Rural courts, notaries and credit in the county of Empúries, 1290-1348

PIOTR GUZOWSKI Village court records and peasant credit in fifteenth- and sixteenth-century Poland

BOOK REVIEWS

HEATHER FALVEy Review of John Broad ed., Bishop Wake's summary of visitation returns from the Diocese of Lincoln 17061715, Part 1, Lincolnshire and Part 2, Outside Lincolnshire MALCOLM GASKILL Review of Annabel Gregory, Rye spirits: faith, faction and fairies in a seventeenth-century English town

William A. CHRISTIAN JR Review of M. Lyons, The writing culture of ordinary people in Europe, c. 1860-1920

jonathan healey Review of Marjorie Keniston McIntosh, Poor relief and community in Hadleigh, Suffolk 1547-1600 


\section{CONTINUITY AND CHANGE 29:2}

\section{ARTICLES}

GILL NEWTON Clandestine marriage in early modern London: when, where and why?

JEREMY BOULTON Traffic in corpses and the commodification of burial in Georgian London

MAÏKA DE KEYZER, IASON JONGEPIER AND TIM SOENS

Consuming maps and producing space. Explaining regional variations in the reception and agency of mapmaking in the Low Countries during the medieval and early modern periods

PIET VAN CRUYNINGEN From disaster to sustainability: floods, changing property relations and water management in the south-western Netherlands, c.1500-1800

Luigi lorenzetti Agricultural specialisation and the land market: an examination of the dynamics of the relationship in the Swiss Alps, c.1860-1930

\section{BOOK REVIEWS}

Gabriel paquette Review of John K. Thornton, $A$ cultural history of the Atlantic world, 1250-1820

JOHN JORDAN Review of Maria R. Boes, Crime and punishment in early modern Germany: courts and adjudicatory practices in Frankfurt am Main, 1562-1696

\section{CONTINUITY AND CHANGE 29:3}

\section{ARTICLES}

SANDY BARDSLEY Peasant women and inheritance of land in fourteenth-century England

KIM OVERLAET Replacing the family? Beguinages in early modern western European cities: an analysis of the family networks of beguines living in Mechelen (1532-1591)

MATTHEW LOCKWOOD 'Love ye therefore the strangers':

immigration and the criminal law in early modern England

CARMEN M. MANGION Housing the 'decayed members' of the middle classes: social class and St Scholastica's Retreat, 1861-1901 
JANE GRAY The circulation of children in rural Ireland during the first half of the twentieth century

BOOK REVIEWS

DAVID GREEN Review of Alysa Levene, The childhood of the poor: welfare in eighteenth-century London

Helena DA Silva Review of Vincent Gourdon, Histoire des grands-parents 


\section{Author Index}

\section{CONTINUITY AND CHANGE VOL. 29}

\section{Articles}

BARDSLEY, SANDY Peasant women and inheritance of land in fourteenth-century England

BOULTON, JEREMY Traffic in corpses and the commodification of burial in Georgian London

BRIGGS, CHRIS Introduction: law courts, contracts and rural society in Europe, $1200-1600$

DE KEYZER, MAÏKA, IASON JONGEPIER AND TIM SOENS Consuming maps and producing space. Explaining regional variations in the reception and agency of mapmaking in the Low Countries during the medieval and early modern periods

GRAY, JANE The circulation of children in rural Ireland during the first half of the twentieth century

GUZOWSKI, PIOTR Village court records and peasant credit in fifteenth- and sixteenth-century Poland

LOCKWOOD, MATTHEW 'Love ye therefore the strangers': immigration and the criminal law in early modern England

LORENZETTI, LUIGI Agricultural specialisation and the land market: an examination of the dynamics of the relationship in the Swiss Alps, c. $1860-1930$

MANGION, CARMEN M. Housing the 'decayed members' of the middle classes: social class and St Scholastica's Retreat, 1861-1901

MARFANY, JULIE AND MARY LOUISE NAGATA Farewells, welcomes and grateful thanks

NEWTON, GILL Clandestine marriage in early modern London: when, where and why?

OVERLAET, KIM Replacing the family? Beguinages in early modern western European cities: an analysis of the family networks of beguines living in Mechelen (1532-1591)

SALES I FAVÀ, LLUís Suing in a local jurisdictional court in late medieval Catalonia. The case of Caldes de Malavella (1328-1369)

SOLDEVILA I TEMPORAL, XAVIER Rural courts, notaries and credit in the county of Empúries, 1290-1348

VAN CRUYNINGEN, PIET From disaster to sustainability: floods, changing property relations and water management in the south-western Netherlands, c. $1500-1800$ 
ZUIJDERDUIJN, JACO On the home court advantage. Participation of locals and non-residents in a village law court in sixteenth-century Holland

\section{Book Reviews}

CHRISTIAN JR, WILLIAM A. Review of M. Lyons, The writing culture of ordinary people in Europe, c. 1860-1920

DA SILVA, HELENA Review of Vincent Gourdon, Histoire des grands-parents

FALVEY, HEATHER Review of John Broad ed., Bishop Wake's summary of visitation returns from the Diocese of Lincoln 1706-1715, Part 1, Lincolnshire and Part 2, Outside Lincolnshire

GASKILL, MALCOLM Review of Annabel Gregory, Rye spirits: faith, faction and fairies in a seventeenth-century English town

GREEN, DAVID Review of Alysa Levene, The childhood of the poor: welfare in eighteenth-century London

healey, Jonathan Review of Marjorie Keniston McIntosh, Poor relief and community in Hadleigh, Suffolk 1547-1600

JORDAN, JOHN Review of Maria R. Boes, Crime and punishment in early modern Germany: courts and adjudicatory practices in Frankfurt am Main, 1562-1696

Paquette, Gabriel Review of John K. Thornton, A cultural history of the Atlantic world, 1250-1820 


\section{CAMBRIDGE JDURNALS}

\section{Rural \\ History}

Economy, Society, Culture

\section{Editors}

Liz Bellamy, University of East Anglia, UK Keith D. M. Snell, University of Leicester, UK Tom Williamson, University of East Anglia, UK

Rural History is well known as a stimulating forum for interdisciplinary exchange. Its definition of rural history ignores traditional subject boundaries to encourage the cross-fertilisation that is essential for an understanding of rural society. It stimulates original scholarship and provides access to the best of recent research. While concentrating on the English-speaking world and Europe, the journal is not limited in geographical coverage. Subject areas include: agricultural history; historical ecology; folklore; popular culture and religion; rural literature; landscape history, archaeology and material culture; vernacular architecture; ethnography, anthropology and rural sociology; the study of women in rural societies; relationships between the urban and the rural; and the politics of rural societies. The journal accommodates varying disciplinary reference systems, and publishes book reviews and review articles.

Rural History is now indexed in the Thomson Reuters JCR

(nisit: http://journals.cambridge.org/ruh

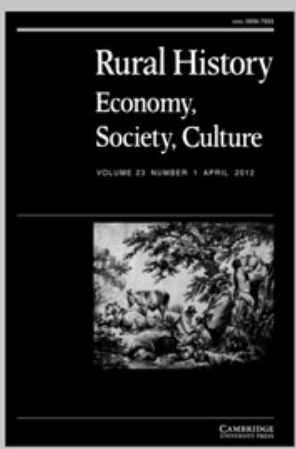

Rural History: Economy,

\section{Society, Culture}

is available online at:

http://journals.cambridge.org/ruh

\section{To subscribe contact}

Customer Services

\section{Americas:}

Phone +1 (845) 3537500

$\mathrm{Fax}+1(845) 3534141$

Email

subscriptions_newyork@cambridge.org

\section{Rest of world:}

Phone +44 (0) 1223326070

$\mathrm{Fax}+44(0) 1223325150$

Email journals@cambridge.org

\section{Free email alerts}

Keep up-to-date with new material - sign up at journals.cambridge.org/register

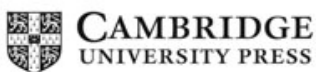




\section{JOURNALS}

\section{Contemporary European History}

\section{Editors}

N. Piers Ludlow, London School of Economics and Political Science, UK Josie McLellan, University of Bristol, UK

Jessica Reinisch, Birkbeck, University of London, UK

Contemporary European History covers the history of Eastern and Western Europe, including the United Kingdom, from 1918 to the present. By combining a wide geographical compass with a relatively short time span, the journal achieves both range and depth in its coverage. It is open to all forms of historical inquiry - including cultural, economic, international, political and social approaches - and welcomes comparative and transnational analysis. One issue per year explores a broad theme under the guidance of a guest editor. The journal regularly features contributions from scholars outside the Anglophone community and acts as a channel of communication between European historians throughout the continent and beyond it.

To subscribe contact Customer Services

\section{in Cambridge:}

Phone $+44(0) 1223326070$

$\mathrm{Fax}+44(0) 1223325150$

Email journals@cambridge.org

in New York:

Phone +1 (845) 3537500

$\mathrm{Fax}+1(845) 3534141$

Email

subscriptions_newyork@cambridge.org

\section{Free email alerts}

Keep up-to-date with new material - sign up at

journals.cambridge.org/register 


\section{CAMBRIDGE JOURNALS}

\section{Central European History}

Published for the Central European History Society

\section{Editor}

Andrew I. Port, Wayne State University, USA

Associate Editor (Book Reviews)

Julia Torrie, St. Thomas University, Canada

Central European History offers articles, review essays, and book reviews that range widely through the history of Germany, Austria, and other German-speaking regions of Central Europe from the medieval era to the present. All topics and approaches to history are welcome, whether cultural, social, political, diplomatic, intellectual, economic, and military history, as well as historiography and methodology. Contributions that treat new fields, such as post-1945 and post-1989 history, maturing fields such as gender history, and less-represented fields such as medieval history and the history of the Habsburg lands are especially desired.

\section{Membership}

Becoming a member of the Central European History Society is easy! Membership comes with a subscription to the journal Central European History (CEH). Subscribe to the journal and join the group.

Yearly dues for $C E H$ are $\$ 42$ for full members and $\$ 27$ for student members. For an additional $\$ 10$ the member receives online access to all volumes of the journal.

Subscribing to $C E H$ is easy via the CEH website. To get there, follow the link: http://journals.cambridge.org/CEHS

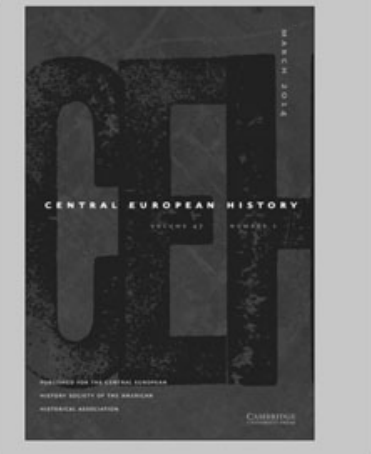

Central European History is available online at: http://journals.cambridge.org/ccc

\section{To subscribe contact Customer Services}

\section{in Cambridge:}

Phone +44 (0) 1223326070

$\mathrm{Fax}+44(0) 1223325150$

Email journals@cambridge.org

\section{in New York:}

Phone +1 (845) 3537500

$\mathrm{Fax}+1(845) 3534141$

Email

subscriptions_newyork@cambridge.org

\section{Free email alerts}

Keep up-to-date with new material - sign up at journals.cambridge.org/register 


\section{JOURNALS}

\section{International Labor and Working-Class History}

Published for International Labor and Working-Class History, Inc.

\section{Senior Editors}

Carolyn Brown, Rutgers University, USA

Jennifer Klein, Yale University, USA

Prasannan Parthasarathi, Boston College, USA

ILWCH has an international reputation for scholarly innovation and quality. It explores diverse topics from globalisation and workers' rights to class and consumption, labour movements, class identities and cultures, unions, and working-class politics. ILWCH publishes original research, review essays, conference reports from around the world, and an acclaimed scholarly controversy section. Comparative and crossdisciplinary, the journal is of interest to scholars in history, sociology, political science, labor studies, global studies, and a wide range of other fields and disciplines.

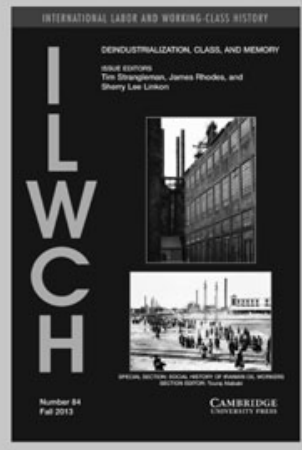

International Labor and Working-Class History

is available online at:

http://journals.cambridge.org/ilw

To subscribe contact

Customer Services

\section{in Cambridge:}

Phone $+44(0) 1223326070$

$\mathrm{Fax}+44(0) 1223325150$

Email journals@cambridge.org

\section{in New York:}

Phone +1 (845) 3537500

$\mathrm{Fax}+1(845) 3534141$

Email

subscriptions_newyork@cambridge.org

\section{Free email alerts}

Keep up-to-date with new material - sign up at

journals.cambridge.org/register 


\section{International Review of Social History}

Published for the Internationaal Instituut voor Sociale Geschiedenis

\section{Executive Editor}

David Mayer, International Institute of Social History, The Netherlands

International Review of Social History is one of the leading journals in its field. Truly global in its scope, it focuses on research in social and labour history from a comparative and transnational perspective, both in the modern and in the early modern period, and across periods. The journal combines quality, depth and originality of its articles with an open eye for theoretical innovation and new insights and methods from within its field and from contiguous disciplines. Besides research articles, it features surveys of new themes and subject fields, a suggestions and debates section, review essays and book reviews.

\section{To subscribe contact}

Customer Services

\section{Americas:}

Phone +1 (845) 3537500

$\mathrm{Fax}+1(845) 3534141$

Email

subscriptions_newyork@cambridge.org

\section{Rest of world:}

Phone +44(0) 1223326070

$\mathrm{Fax}+44(0) 1223325150$

Email journals@cambridge.org

\section{Free email alerts}

Keep up-to-date with new material - sign up at

journals.cambridge.org/register

For free online content visit: http://journals.cambridge.org/ish 


\section{CAMBRIDGE J JUNALS}

\section{Journal of Global History}

Published for London School of Economics and Political Science

\section{Chief Editor}

William Gervase Clarence-Smith, SOAS, London, UK

\section{Editors}

Barbara Watson Andaya, University of Hawail, USA

Merry Wiesner-Hanks, University of Wisconsin-Milwaukee, USA

Journal of Global History addresses the main problems of global change over time, together with the diverse histories of globalization. It also examines countercurrents to globalization, including those that have structured other spatial units. The journal seeks to transcend the dichotomy between 'the West and the rest', straddle traditional regional boundaries, relate material to cultural and political history, and overcome thematic fragmentation in historiography. The journal also acts as a forum for interdisciplinary conversations across a wide variety of social and natural sciences.

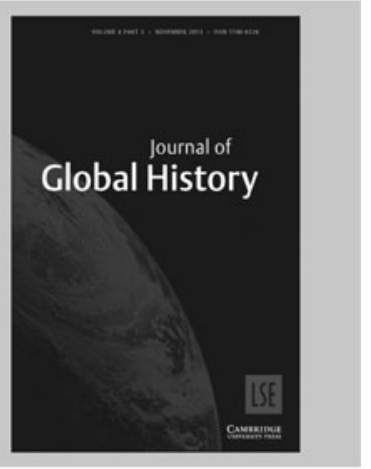

\section{Journal of Global History} is available online at: http://journals.cambridge.org/jgh

To subscribe contact Customer Services

\section{Americas:}

Phone +1 (845) 3537500

$\mathrm{Fax}+1(845) 3534141$

Email

subscriptions_newyork@cambridge.org

\section{Rest of world:}

Phone +44(0) 1223326070

$\mathrm{Fax}+44(0) 1223325150$

Email journals@cambridge.org

Free email alerts

Keep up-to-date with new material - sign up at

journals.cambridge.org/register 


\section{CAMBRIDGE JDURNALS}

\section{Urban History}

\section{Editors}

Shane Ewen, Leeds Metropolitan University, UK

Simon Gunn, University of Leicester, UK

Rosemary Sweet, University of Leicester, UK

North American Editor

Robert D. Lewis, University of Toronto, Canada

Multimedia Editor

Philip J. Ethington, University of Southern California, USA

Urban History occupies a central place in historical scholarship, with an outstanding record of interdisciplinary contributions, and a broad-based and distinguished panel of referees and international advisors. Each issue features wide-ranging research articles covering social, economic, political and cultural aspects of the history of towns and Cities. Urban History is leading the way in academic publishing with its multimedia companions. The companions are refereed and fully linked and provide real depth to research. Online subscribers also gain access to Urban History's comprehensive online bibliography, which contains 34,000 searchable items including books, articles and edited collections.

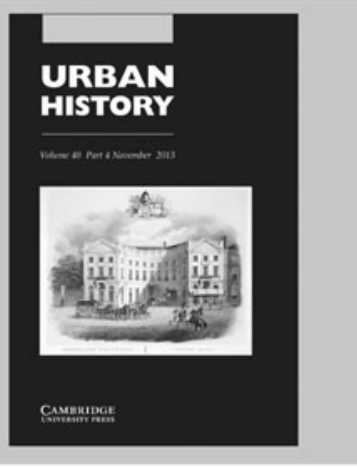

\section{Urban History}

is available online at:

http://journals.cambridge.org/uhy

\section{To subscribe contact}

Customer Services

\section{Americas:}

Phone +1 (845) 3537500

Fax $+1(845) 3534141$

Email

subscriptions_newyork@cambridge.org

\section{Rest of world:}

Phone +44(0)1223 326070

$\mathrm{Fax}+44(0) 1223325150$

Email journals@cambridge.org

\section{Free email alerts}

Keep up-to-date with new material - sign up at

journals.cambridge.org/register

For free online content visit: http://journals.cambridge.org/uhy

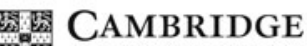
UNIVERSITY PRESS 


\section{NOTES FOR CONTRIBUTORS}

Continuity and Change aims to define a field of historical sociology concerned with long-term continuities and discontinuities in the structure of past societies. Emphasis is upon studies whose agenda or methodology combines elements from traditional fields such as history, sociology, law, demography, economics or anthropology, or ranges freely between them. There is a strong commitment to comparative studies over a broad range of cultures and time spans.

\section{Editors}

Dr Chris Briggs, Selwyn College, Cambridge CB3 9DQ, UK. email:cdb23@cam.ac.uk

Dr Susan Leonard, University of Michigan, P.O. Box 1248 Ann Arbor, MI 48106-1248. email: hautanie@umich.edu

Dr Mary Louise Nagata, Francis Marion University, Department of History, 4822 E. Palmetto, Florence, SC 29506, USA.

email:mnagata@fmarion.edu

Dr Julie Marfany, Department of History, University of Durham, 43 North Bailey, Durham DH1 3EX, UK.

email: julie.marfany@durham.ac.uk

Books for review should be sent to the Book Review Editor, Gill Newton, at the following address: Cambridge Group for the History of Population and Social Structure, Department of Geography, Downing Place, Cambridge, CB2 3EN, UK.

1. Articles should usually be less than 10,000 words, including endnotes and a 100-word abstract. Texts should be double-spaced throughout and on one side of the paper only, with generous margins and submitted by email as Word files to each of the Editors. The title page should indicate the word-length of the article and affiliation and contact address of the author(s). Comments on previously published articles will also be considered, provided they do not exceed 1500 words.

2. Endnotes should be numbered consecutively through the manuscript and typed double-spaced on separate pages at the end. Bibliographical references should be given in full in the endnotes when first cited; thereafter use author surname and short title.

3. Maps and graphs (figures) and tables should be submitted in separate files, and the text annotated to indicate where they should be placed. Figures should be submitted as tif or eps files.

4. British conventions for spelling and punctuation are followed.

5. The Editors reserve the right to request authors to meet the costs of major correction to the English that they consider necessary after the articles have been reviewed and resubmitted by the authors.

6. Authors of articles published in the journal assign copyright to Cambridge University Press (with certain rights reserved).

A full set of conventions is available on our website at: journals.cambridge.org/con.

This journal issue has been printed on FSC-certified paper and cover board. FSC is an independent, non-governmental, not-for-profit organization established to promote the responsible management of the world's forests. Please see www.fsc.org for information. 


\section{CONTENTS}

SANDY BARDSLEY, Peasant women and inheritance of land in fourteenth-century England

KIM OVERLAET, Replacing the family? Beguinages in early modern western European cities:

an analysis of the family networks of beguines living in Mechelen (1532-1591)

MATTHEW LOCKWOOD, 'Love ye therefore the strangers': immigration and the criminal law in early modern England

CARMEN M. MANGION, Housing the 'decayed members' of the middle classes: social class and St Scholastica's Retreat, 1861-1901

JANE GRAY, The circulation of children in rural Ireland during the first half of the twentieth century

\section{FORTHCOMING}

FREDERIK BUYLAERT and ANDY RAMANDT,

The transformation of rural elites in late medieval Flanders: oligarchy, state formation and social change in the liberty of Bruges (c. 1350-c. 1525)

CHRISTIAAN VAN BOCHOVE, HEIDI DENEWETH and JACO ZUIJDERDUIJN, Real estate and mortgage finance in England and the Low Countries, 1300-1800

Front cover illustration: The Widow Magdalena Rothgerb, Lorenz Heid, Berlin 1746

\section{Cambridge Journals Online}

For further information about this journal please go to the journal website at: journals.cambridge.org/con

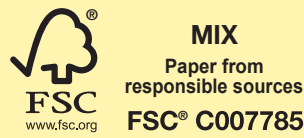

$\underset{\text { UNIVERSITY PRESS }}{\text { CAMBRIDGE }}$ 